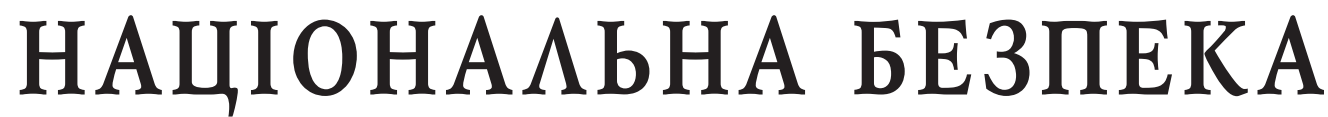

\author{
DOI: https://doi.org/10.32839/2304-5809/2021-3-91-6 \\ УДК 327:35.073.5H(470)
}

Гунько Л.В., Задорожний В.П.

Національна академія сухопутних військ

\section{ВПЛИВ КРИЗОВИХ ЯВИЩ ВПРОДОВЖ 2020 РОКУ У ДЕЯКИХ СУМІЖНИХ З РФ КРАЇНАХ ТА ЗАГРОЗИ ЇХ НАЦІОНАЛЬНІЙ БЕЗПЕЦІ}

Анотація. В статті розглянуті основні події внутрішньо-політичних процесів у деяких країнах пострадянському простору в 2020 рощі та висвітлено характер змін російського впливу на країни «близького зарубіжжя». Впродовж останніх десятка років Російська Федеращія стикається з багатьма проблемами у стосунках 3 колишніми республіками з часу розпаду Радянського Союзу. Так, Росія намагалася зберегти свою владу на пострадянському просторі, незважаючи на численні потрясіння, шляхом зміцнення двосторонніх зв’язків та створення багатосторонніх інститущій, які пов'язували колишні радянські республіки із своїм колишнім мегаполісом. Зокрема, з серпня 2020 року демонстранти в Білорусі почали влаштовувати щотижневі акції протесту проти фральсифікації президентських виборів, на яких «офіційно» переміг багаторічний лідер Олександр Лукашенко. Водночас, у вересні 2020 року, почалася війна між Вірменією та Азербайджаном через спірну територію Нагірного Карабаху. Крім того, у жовтні 2020 року масові протести призвели до повалення президента Киргизстану Сооронбея Жеенбекова. Всі ці події здивували Росію своїм швидким розвитком кризових явищ. Навіть бути наймогутнішим сусідом РФ вимагає розуміння подій у пострадянських державах i, звичайно, вимагає ресурсів для підтримки цього статусу. Чим далі від радянської тіні, тим більш відокремленими від Кремля стають ці держави і тим більше диференціюються одна від одної. А це означае, що внутрішня політика в інших пострадянських державах стае непередбачуваною для РФ.

Ключові слова: протести, національна безпека, збройний конфрлікт, регіональна політика, російський вплив.

\section{Gunko Leonid, Zadorozhnyi Volodymyr} National Army Academy

\section{THE IMPACT OF CRISIS PHENOMENA DURING 2020 IN SOME NEIGHBORING COUNTRIES WITH THE RUSSIAN FEDERATION AND THREATS TO THEIR NATIONAL SECURITY}

Summary. Since the collapse of the Soviet Union, Russia has sought to maintain its sway in the post-Soviet space despite numerous upheavals. It has worked to solidify bilateral ties and create multilateral institutions to bind the ex-Soviet republics to their former metropole. However, 2020 was not kind to Russia's ambitions in its near-abroad. In August 2020, demonstrators in Belarus began staging weekly protests against rigged presidential elections, won «officially» by long-standing leader Alexander Lukashenko. Then, in September, war erupted between Armenia and Azerbaijan over the disputed territory of Nagorno-Karabakh. Additionally, in October, violent protests led to the ouster of Kyrgyz president Soornonbay Jeenbekov. Russia seemed surprised by the rapid succession of crises. The unrest in Kyrgyzstan was jarring for Putin, but Russia's privileged role in the country's politics likely remains secure. His influence over Belarus is more tenuous; the anti-Lukashenko demonstrations continue even as Putin continues to advocate Belarus's incorporation into Russia despite public opposition in both countries. The war in Nagorno-Karabakh, though it ended with Russian peacekeepers patrolling key contested areas, may also signal Russia's declining influence in its near-abroad. The landscape has changed, and Russia's limited resources may finally be constraining its regional policy. Even being the most «powerful neighbor» necessitates a nuanced understanding of events in the post-Soviet states and of course requires resources to support its status. The further out from the Soviet shadow, the more separate from the Kremlin these states become the more differentiated from one another. Indeed, if there is one lesson that the Kremlin has had difficulty learning, it is that events - especially domestic politics in the other post-Soviet states - are unpredictable.

Keywords: protests, national security, armed conflict, regional policy, Russian influence.

$\Pi$ остановка проблеми. Геополітичне становище держави визначаеться не тільки фізичною географрією, але й змінами у світовому геополітичному порядку та глобальній економіці. Після розпаду СРСР геополітичний статус Росії, як спадкоемниці цієї держави, значно зменшився, а цей фокт привів до того, що на пострадянському просторі почали формуватися інші центри сили. Так, з пострадянськими республіками активно взаемодіють США, країни ЄС, Китай, Туреччина, Іран тощо.
Тобто за останні десятиліття структура пострадянського простору якісно змінилася, оскільки активізувалися регіональні й глобальні центри впливу, які конкурують з РФ у процесах розробки та реалізації власних інтеграційних проектів.

Зважаючи на згадані вище фактори, здійснення об’єктивного аналізу нинішнього стану євразійської інтеграції, яка реалізуеться на пострадянському просторі, та процесів, які відбуваються навколо нього загалом, зіставлення позицій провідних акторів інтеграційного процесу, 
оцінка перспектив інтеграції, виходячи 3 критичної оцінки позиції та інтересів РФ і загальної геополітичної ситуації у світі, а також зміни балансу сил і влади у регіоні й світі, видаються надзвичайно актуальними.

Це також має важливе значення для України, перед якою гостро постає проблема забезпечення національної безпеки в умовах формування свого безпекового середовища.

Аналіз останніх досліджень та публікацій. Розгляд пострадянського простору та вивчення процесу становлення й етапів інституціоналізації безпекової політики РФ у пострадянський період здійснив Мельничук I.M. у своїй дисертаційній роботі «Інтеграційні проекти Російської Федерації на пострадянському просторі» (2015), а Ткаченко В.М. у своїй монографії «Росія: ідентичність агресора» (2016) висвітлив агресивну сутність «путінізму", дискредитащію нового світового порядку і нав'язування «іншого світу». Стан та розвиток внутрішньої та зовнішньої політики Російської Федерації подається в аналітичній доповіді Центру досліджень проблем Російської Федеращії Національного інституту стратегічних досліджень «Режим Путіна перед викликами часу» (2017).

Мета статті - показати основні події внутрішньо-політичних процесів в деяких країнах пострадянському простору у 2020 рощі та характер змін російського впливу на країни «близького зарубіжжя.

Викладення основного матеріалу. Впродовж останніх десятка років Російська Федерація стикаеться 3 багатьма проблемами у стосунках 3 колишніми республіками, а саме з часу розпаду Радянського Союзу в грудні 1991 року. Росія намагалася зберегти свою владу на пострадянському просторі, незважаючи на численні потрясіння, шляхом зміцнення двосторонніх зв'язків та створення багатосторонніх інституцій, які пов'язували колишні радянські республіки зі своїм колишнім мегаполісом. Так, з серпня 2020 року демонстранти в Білорусі почали влаштовувати щотижневі акції протесту проти фральсифікації президентських виборів, у вересні 2020 року почалася війна між Вірменією та Азербайджаном через спірну територію Нагірного Карабаху, а у жовтні 2020 року масові протести призвели до повалення президента Киргизстану. Незважаючи на привілейовану роль Росії в політиці Киргизстану, протестні хвилі в країні були для президента РФ В. Путіна неприємними. Иого вплив на Білорусь є більш слабким. Демонстрації проти О. Лукашенко продовжуються, навіть коли В. Путін продовжуе виступати за приеднання Білорусі до Росії, незважаючи на громадський спротив в обох країнах. Війна в Нагірному Карабасі, хоч і закінчилася тим, що російські миротворці патрулюють ключові суперечливі райони, може також сигналізувати про зниження впливу Росії в ії «близькому зарубіжжі». Ландшарт змінився, і обмежені ресурси Росії можуть стримувати їі регіональну політику. Всі ці події здивували Росію своїм швидким розвитком кризових явищ.

Політичні експерти стверджують, що В. Путін боїться «влади людей», тобто громадян, які виходять на вулиці, щоб скинути корумпованих, авторитарних лідерів, особливо на пострадянському просторі. 3 часів «революції троянд» у Грузії 2003 року В. Путін все частіше вважає, що ці приклади "народної влади» західні країни пропагували і продовжують просовувати. Гірше того, В. Путін боїться потенційного демонстраційного ефекту таких повстань. Якщо корумпованого авторитарного лідера скинуть в одній із держав-наступниць, який вплив це може мати на російських громадян? Це витікає із відповіді Росії на події як в Киргизстані, так і в Білорусі.

Хоч Киргизстан не є в епіцентрі політичних заголовків засобів масової інформації в останній період часу, потенціал нестабільності там триває. Враховуючи розташування Киргизстану в центрі Середньої Азії та сусідство 3 Китаєм, Росія навряд чи могла проігнорувати потрясіння. Кремль має там дві військові бази. В той же час, Киргизстан є членом Свразійського економічного союзу та Організації Договору про колективну безпеку. Нестабільність в країні розпочалася 4 жовтня 2020 року, коли фральсифікація парламентських виборів призвела до перемог партій, які співпрацювали з тодішнім президентом С. Жеенбековим [1]. Протестуючі вийшли на вулиці та напали на державні установи країни, звільнивши політичних в'язнів, зокрема екс-президента А. Атамбаєва та депутата парламенту С. Джапарова [2]. По міри того, як влада Жеенбекова не реагувала і вона виявилася нездатною контролювати вулицю, Кремль намагався досягти домовленості між С. Жеенбековим та опозицією. 12 жовтня 2020 року Дмитро Козак, заступник глави адміністрації президента РФ, прибув до Бішкека, намагаючись домовитись між популістом С. Джапаровим та С. Жеенбековим [3]. Як зазначають політичні аналітики, зокрема Еріка Марат, С. Жеенбеков ніколи не знаходив твердої «опори» з Москвою, i, незважаючи на деякі чутки про російську підтримку, між Москвою та Бішкеком не було явної координації щодо утримання його на посаді після виборів [4]. За кілька днів після невдалого посередництва С. Жеенбеков подав у відставку, залишивши владу С. Джапарову, який пізніше став прем'єр-міністром і виконуючим обов'язки президента, а також зміцнив свою владу шляхом конституційних змін, які перетворили Киргизстан на міцну президентську систему. Відомо, що з 2005 року в Киргизстані відбулась третя зміна керівництва. У кожному випадку протести проти виборчих порушень та корупції призвели до нових урядів. Росія активніше втрутилася в 2010 році, натиснувши на тодішнього президента Курманбека Бакієва 3 метою закриття американської бази в Манасі [5]. Цього разу потрясіння видаються спонтанними, і реакція Росії була зосереджена на забезпеченні стабільності. Малоймовірно, що будь-який президент Киргизстану змістить Бішкек з орбіти Росіі. Країна занадто бідна і занадто залежить від грошових переказів киргизів, які проживають у Російській Федерації. Отже, очевидним $\epsilon$ те, що справді вразило владу в Москві, це приклад нестабільності та народних заворушень.

Те саме можна сказати про численні демонстрації проти білоруського президента О. Лукашенко. Білоруський президент постійно применшував пандемію Ковід-19, навіть доходячи до того, що вважав горілку ліками. Коли люди зіткнулися 3 явно сфральсифікованими прези- 
дентськими виборами, тисячі людей вийшли на вулиці [6]. Жорстока реакція білоруської влади, яка включала побиття та катування, ще більше розпалила опозицію і протести поширилися за межі Мінська. О. Лукашенко був неохочим партнером В. Путіна. Білорусь, яка давно залежала від російських субсидій, часом намагалася отримати їі в обох напрямках. У 1999 року вона підписала угоду про «союзну державу» 3 Москвою, але чинила опір тиску з метою перетворення ціеї угоди в реальність. Хоча Білорусь є однією з первинних підписантів Свразійського економічного союзу та Організації Договору про колективну безпеку, О. Лукашенко набрав більш зухвалого тону після анексії Криму і відмовився розташовувати російську військову базу всередині своєї країни. Зіткнувшись 3 найсерйознішою загрозою для його утримання, О. Лукашенко погодив свою відповідь з Москвою. На думку більшості спостерігачів, основна угода Мінська та Москви полягає у тому, що О. Лукашенко виключає вплив Заходу на Білорусь в обмін на економічну та політичну підтримку. Коли О. Лукашенко прилетів до Сочі в середині вересня 2020 р., щоб зустрітися з В. Путіним, пропозиція щодо розміщення російської військової бази а Білорусі тоді була актуальною [7]. Для того, щоб запобігти краху білоруської економіки та дати Мінську час на вирішення кризи, В. Путін виділив 1,5 мільярда доларів позики. Зі свого боку, О. Лукашенко стверджував, що Захід розпалює заворушення. Цим самим, ймовірно, він сподівався спокусити Росію на допомогу, не маючи зайвої поступки Москві. У довгостроковій перспективі В. Путін тиснув на О. Лукашенко з метою більшого російського впливу і закликав О. Лукашенко внести зміни до конститущї, щоб зменшити кризу. О. Лукашенко, здавалося б, підігрів ідею конституційних змін. Він розглядає зміни до конституції щодо зменшення президентської влади як спосіб розколу опозищії. В той же час Москва розглядає конституційні зміни як спосіб звільнити його з посади.

Наразі протистояння триває. Лідер опозиції Світлана Тихановська залишаеться в еміграції і їі підтримуе Західна Свропа. О. Лукашенко оголосив, що покине посаду після узгодження конституційних змін, проте опозиція хоче спочатку вільних i чесних виборів. Росія опинилася в ситуації «без виграшу». О. Лукашенко є системою і у випадку його звільнення від посади це загрожуе крахом структури влади в країні. Як альтернатива, якщо О. Лукашенко покине свою посаду, то світ сприйме це як витіснення його «народною владою».

Якщо політичні заворушення в Киргизстані та Білорусі випробовували поведінку Росії з «народною владою», то війна в Нагірному Карабасі поставила під сумнів роль Москви як важливої держави на Південному Кавказі і загрожувала здатності Кремля стримувати багаторічні бойові дії між Вірменією та Азербайджаном. Остання війна бере свій початок від розпаду Радянського Союзу, коли етнічно вірменський Нагірний Карабах за підтримки Єревана проголосив незалежність від Азербайджану. У 1994 рощі російськопосередницьке припинення вогню припинило насильство, але вірмени залишили керівництво Нагірного Карабаху та окупували навколишні сім районів. Протягом 26 років Азербайджан зазнавав збитків і чекав можливості відновити свою територіальну цілісність. Протягом усього періоду Кремль підтримував тісні зв'язки 3 Вірменією і одночасно розвивав значні економічні зв'язки з Азербайджаном, включаючи продаж зброї та нафртогазові угоди.

Ця війна виявилася суттєво відмінною від попередніх спалахів у кількох фрундаментальних аспектах. По-перше, Баку озброєний краще, ніж був у минулому: президент Ільхам Аліев використовував прибутки Азербайджану від нафрти і газу для придбання зброї у Росії та безпілотників як з Туреччини, так і з Ізраїлю. Справді, турецькі безпілотники виявились вирішальними у війні. Подруге, Туреччина стала головним гравцем у регіоні та за його межами. Влітку 2020 року Туреччина та Азербайджан провели спільні військові навчання, а президент Туреччини Реджеп Таїп Ердоган закликав до повного виведення Вірменії з Нагірного Карабаху. По-трете, Кремль критично відносився щодо прем'ер-міністра Вірменії Н. Пашаняна, оскільки він у 2018 рощі вступив на посаду після народних демонстрацій проти свого попередника [8]. 3 початком своїх повноважень Н. Пашанян наполягав на тому, щоб влада Карабаху була залучена до будь-яких мирних переговорів і офріційно закликав об'єднати Нагірний Карабах із Вірменією всупереч Мадридським принщипам попередньої домовленості (яка вимагала від Вірменії поступитися контролем над семи окупованими районами та взяти участь у подальших переговорах про статус спірних територій).

На думку деяких аналітиків, В. Путін цілком міг бути роздратований непоступливістю Н. Пашаняна i, можливо, навіть сигналізував Баку про те, як далеко можуть зайти азербайджанські сили. Росія, звичайно, дозволила війні тривати кілька тижнів. Після кількох тисяч загиблих, численних невдалих спроб припинення вогню та значних азербайджанських військових успіхів Москві вдалося домовитись, щоб вірмени вийшли 3 семи районів Карабаху і російські миротворці були розміщені в цих районах. Лачинський коридор, який з'єднуе Нагірний Карабах і власне Вірменію, патрулюеться російськими військами, i $є$ коридором довжиною у 50 км, який зв'язує Азербайджан 3 Нахічеваном (етнічним азербайджанським анклавом у межах Вірменії). Припинення вогню також сприяло створенню спільного російсько-турецького центру моніторингу. Найголовніше, що для Вірменії результатом війни стала принизлива поразка. На противагу цьому, Азербайджан святкував перемогу, якої він прагнув протягом останніх 26 років. Можливо, для посилення підтримки Вірменії В. Путін на зустрічі в Москві 11 січня 2021 року запропонував плани покінчити з географічною та торговою ізоляцією Єревана [9]. Для Туреччини участь у війні та підтримка Баку є формалізацією ролі Анкари як кавказької держави. Р. Ердоган фрактично кинув виклик монополії Москви в цьому регіоні.

3 часів розпаду Радянського Союзу, i, безумовно, 3 часу вторгнення та анексії Криму, переважаючим наративом російської політики щодо радянських держав-наступниць є втручання, маніпуляції та розширення впливу Москви. Всі кризові явища, що відбулися минулого року, безперечно, ілюструють нову модель. 
Так, у Киргизстані С. Джапаров з великим відривом переміг у президентських виборах 10 січня 2021 року, але наскільки стабільним буде його уряд, ще $є$ не зрозумілим [10]. Під час кампанії С. Джапаров давав щедрі обіцянки населенню, і він, очевидно, усвідомлюе, що йому знадобиться підтримка Росії, щоб досягти успіху. 3 огляду на економічні обмеження Москви, незрозуміло, скільки Росія зможе надати допомоги. Незважаючи на помірний характер ситуації, представляеться малоймовірним, що Кремль більш безпосередньо захоче втручатися у киргизькі події.

Білоруська криза здається більш нерозв'язаною. Москва, хоч і не бажає застосовувати силу, зберігае військовий варіант. Зокрема, у листопаді 2020 року Росія та Білорусь підписали угоду, яка дозволяе будь-якій стороні проводити правоохоронні операції, якщо «така допомога представляе інтерес для іншої» [11]. Для Росії немае простої відповіді. Якщо Кремль просуне об'єднання, білоруський народ, який виступае проти вступу до Росії, повернеться проти Москви. Ще більше ускладнюючи ситуацію 3 точки зору Кремля, російський народ також не підтримуе поглинання Білорусі. Як варіант, якщо О. Лукашенко зуміе залишитися, Росії доведеться збільшити свої субсидії, щоб утримати його при владі. Будь-яка з цих альтернатив вимагатиме значних інвестищій у дефіцитні ресурси Росії. Але, можливо, і те, i інше було б для Москви більш вигідним, ніж різкий відхід О. Лукашенко зі сцени.

На відміну від драм у Киргизстані чи Білоруci, війна на Кавказі представляе іншу динаміку. Традиційно Росія підтримуе крихкий баланс між Вірменіею та Азербайджаном, що ускладнюеться зростанням глобальних амбіцій Анкари. Якщо, як припускають деякі спостерігачі, Москва надала можливість діяти азербайджанським військовим, то Кремль, швидше за все, втратив підтримку в Сревані. Протести проти Н. Пашаняна вибухнули на вулицях Єревана після відступу Вірменії, загрожуючи як його перебуванню на посаді, так і, можливо, самій угоді. У відповідь В. Путін схвально поставився до дій Н. Пашаняна і закликав колег з Договору про колективну безпеку «підтримати як прем'ер-міністра, так і його команду з метою забезпечення миру». Майбутне незрозуміле. На даний час багато вірмен сумніваються в ролі Росії як «гаранта безпеки та міцного союзника» $[12$, с. 86$]$.

На Південному Кавказі Москва все ще $е$ одним із ключових гравців, якщо не найсильнішим гравцем. Однак вона явно не має контролю над розвитком подій, i іï̈ вплив поступово зменшуеться $з$ позищій колишньої колоніальної метрополії [13, c. 57-58]. Незважаючи на те, що спільний центр моніторингу надае видимість співпраці, Туреччина стає дедалі незалежнішим суб'єктом і готова кинути виклик іншим регіональним та міжнародним гравцям. Що це означає для влади Москви на Кавказі, трохи зрозумілим стане пізніше [14].

Висновки та пропозиції. Навіть бути наймогутнішим сусідом вимагає розуміння подій у пострадянських державах i, звичайно, вимагає ресурсів для підтримки його статусу. Чим далі від радянської тіні, тим більш відокремленими від Кремля стають ці держави і тим більше диференціюються одна від одної. А це означае, що внутрішня політика в інших пострадянських державах стає непередбачуваною для політичного істеблішменту РФ.

У Киргизстані та Білорусі люди вийшли на вулиці на знак протесту проти корупції та політичних маніпуляцій. Проте В. Путін чітко визначає пріоритет стабільності для РФ та продовжуе наполягати на інтеграції з Білоруссю, нехтуючи настроями громадськості. А це означає, що Росії бракуе розуміння до суспільних змін у «близькому зарубіжжі».

Інструменти, які Росія використовувала в минулому для здійснення та збереження свого впливу, зазнали невдачі. Організація Договору про колективну безпеку не надала допомоги своїй країні-члену Вірменії під час війни в Нагірному Карабасі, і Євразійський економічний союз не досяг реальних мір інтеграції. Росія, схоже, не бажае або не може витратити на те, що потрібно було б «завоювати» громадську підтримку в інших колишніх радянських державах.

Москва була різко надламана падінням цін на надрту, пандеміею коронавіруса і супутнім уповільненням економічного зростання. Справді, Кремль не тільки невдало керував пандеміею, але й не використовував капітал для зміцнення своеї економіки, що провалюеться. Постійний застій в економіці та зниження доходів населення підривають довіру до режиму, а мобілізація та пропаганда зовнішньої політики більше не компенсуе «економічний негатив».

Внутрішні та міжнародні обставини нині обмежують російські амбіції та дії. Це не означае, що Росія припинить спроби впливати на події на пострадянському просторі. Але це означае, що Москва матиме дедалі обмеженіші ресурси, щоб виконувати свою стару роль.

\section{Список літератури:}

1. ООН висловлюе стурбованість ситуаціею в Киргизстані. Радіо Свобода. 09.10 .2020$. URL: https://www.radiosvoboda.org/a/news-oon-kyrgyzstan-sturbovanist/30885106.html (дата звернення: 25.03.2021).

2. Екс-президент Киргизстану Атамбаев звільнений 3 СІЗО. Інтерфакс-Україна. 06.10.2020. URL: https://ua.interfax.com.ua/news/general/693130.html (дата звернення: 25.03.2021).

3. В Бишкеке заявили о неоднократных беседах Жээнбекова и Путина. Интерфакс. 13.10.2020. URL: https://www.interfax.ru/world/731264 (дата звернення: 25.03.2021).

4. Эрика Марат: Атамбаев должен выйти на свободу через суд. Gezitter.org. 06.10.2020. URL: https://www.gezitter.org/society/91884_erika_marat_atambaev_doljen_vyiyti_na_svobodu_cherez_sud (дата звернення: 25.03.2021).

5. Президент Киргизстану заявив про погрози його країні через колишню базу США. 24.07.2017. URL: https://www.radiosvoboda.org/a/news/28635878.html (дата звернення: 25.03.2021).

6. Майдан для Лукашенка: як вибори-2020 розбудили Білорусь та на що варто зважати Україні. Свропейська правда. 10.08.2020. URL: https://www.eurointegration.com.ua/articles/2020/08/10/7113009 (дата звернення: 25.03.2021). 
7. Російський кредит, білоруський шпагат: що Путін із Лукашенком наговорили під час зустрічі в Сочі. Громадське ТБ. 14.09.2020. URL: https://hromadske.ua/posts/rosijskij-kredit-biloruskij-shpagat-sho-putin-izlukashenkom-nagovorili-pid-chas-zustrichi-v-sochi (дата звернення: 25.03.2021).

8. Нагірний Карабах: хто виграв і що далі? BBC News/Україна. 11.11.2020. URL: https://www.bbc.com/ukrainian/ features-54887608 (дата звернення: 25.03.2021).

9. Первая встреча лидеров Азербайджана и Армении после войны в Карабахе: без рукопожатий, но с мирными планами. BBC News/Русская служба. 11.01.2021. URL: https://www.bbc.com/russian/news-55620532 (дата звернення: 25.03.2021).

10. Вибори в Казахстані і Киргизстані: підсумки і аналіз. Радіо Свобода. 13.01.2021. URL: https://www.radiosvoboda.org/a/kazaxstan-kyrhyzstan-vybory/31044104.html (дата звернення: 25.03.2021).

11. Білорусь допустила РФ до охорони стратегічних об'єктів та порядку. Укрінформ. 18.12.2020. URL: https://www.ukrinform.ua/rubric-world/3157098-bilorus-dopustila-rf-do-ohoroni-strategicnih-obektiv-taporadku.html (дата звернення: 25.03.2021)..

12. Ткаченко B.М. Росія: Ідентичність агресора : Монографія. Київ : ВЦ «Академія», 2016.256 с. URL: http://elibrary.ivinas.gov.ua/27/1/Rosiya_identychnist_ahresora.pdf (дата звернення: 25.03.2021).

13. Режим Путіна перед викликами часу. Аналітична доповідь / М.М. Розумний, Я.В. Бережний, І.В. Валюшко, P.В. Власенко, за заг ред. М.М. Розумного. Київ : НІСД, 2017. С. 84. URL: https://niss.gov.ua/sites/default/ files/2017-06/Dopovid_Putin-5b78c.pdf (дата звернення: 25.03.2021).

14. «Мы обязательно поедем в те края». Как Турция видит свою роль в миротворческой миссии в Карабахе. BBC News / Русская служба. 13.11.2020. URL: https://www.bbc.com/russian/features-54930755 (дата звернення: 25.03.2021).

\section{References:}

1. The UN is concerned about the situation in Kyrgyzstan. Radio Liberty. 09.10.2020. URL: https://www.radiosvoboda.org/ a/news-oon-kyrgyzstan-sturbovanist/30885106.html (accessed 25 March 2021).

2. Former President of Kyrgyzstan Atambayev has been released from jail. Interfax-Ukraine. 06.10.2020. URL: https://ua.interfax.com.ua/news/general/693130.html (accessed 25 March 2021).

3. Bishkek announced repeated conversations between Jeenbekov and Putin. Interfax. 13.10.2020. URL: https://www.interfax.ru/world/731264 (accessed 25 March 2021).

4. Erica Marat: Atambayev should be released through the courts. Gezitter.org. 06.10.2020. URL: https://www.gezitter.org/ society/91884_erika_marat_atambaev_doljen_vyiyti_na_svobodu_cherez_sud (accessed 25 March 2021).

5. The President of Kyrgyzstan has announced threats to his country through a former US base. 24.07.2017. URL: https://www.radiosvoboda.org/a/news/28635878.html (accessed 25 March 2021).

6. Maidan for Lukashenko: how the 2020 elections woke up Belarus and what to consider Ukraine. Yevropeyska pravda. 10.08.2020. URL: https://www.eurointegration.com.ua/articles/2020/08/10/7113009 (accessed 25 March 2021).

7. Russian credit, Belarusian twine: what Putin and Lukashenko said during the meeting in Sochi. Hromadske TV. 14.09.2020. URL: https://hromadske.ua/posts/rosijskij-kredit-biloruskij-shpagat-sho-putin-iz-lukashenkomnagovorili-pid-chas-zustrichi-v-sochi (accessed 25 March 2021).

8. Nagorno-Karabakh: who won and what's next? BBC News/Ukraine. 11.11.2020. URL: https://www.bbc.com/ ukrainian/features-54887608 (accessed 25 March 2021).

9. The first meeting of the leaders of Azerbaijan and Armenia after the war in Karabakh: without handshakes, but with peaceful plans. BBC News / Russian. 11.01.2021. URL: https://www.bbc.com/russian/news-55620532 (accessed 25 March 2021).

10. Elections in Kazakhstan and Kyrgyzstan: results and analysis. Radio Liberty. 13.01.2021. URL: https://www.radiosvoboda.org/a/kazaxstan-kyrhyzstan-vybory/31044104.html (accessed 25 March 2021).

11. Belarus allowed Russia to protect strategic facilities and order. Ukrinform. 18.12.2020. URL: https://www.ukrinform.ua/rubric-world/3157098-bilorus-dopustila-rf-do-ohoroni-strategicnih-obektiv-taporadku.html (accessed 25 March 2021).

12. Tkachenko V.M. (2016) Russia: The identity of the aggressor: Monograph. Kyiv: Akademiya, pp. 256. URL: http://elibrary.ivinas.gov.ua/27/1/Rosiya_identychnist_ahresora.pdf (accessed 25 March 2021).

13. Putin's regime before the challenges of time. Analytical report (2017) / M.M. Rosumnyi, Y.V. Berezhnyi, I.V. Valyushko, R.V. Vlassenko, ed. M.M. Rosumnyi. Kyiv: NISD, p. 84. URL: https://niss.gov.ua/sites/default/ files/2017-06/Dopovid_Putin-5b78c.pdf (accessed 25 March 2021).

14. «We will definitely go to those parts». How Turkey sees its role in the peacekeeping mission in Karabakh. BBC News / Russian. 13.11.2020. URL: https://www.bbc.com/russian/features-54930755 (accessed 25 March 2021). 